\title{
Acculturation and Identity in the Diaspora: A Jewish Family and 'Pagan' Guilds at Hierapolis ${ }^{1}$
}

\author{
Philip A. Harland \\ York University, Toronto
}

\section{Introduction}

$\mathrm{R}$ ecent studies of the diaspora in the Roman period are beginning to address regional variations among Jewish gatherings and are giving attention to the relationships between these groups and the societies in which they found themselves. ${ }^{2}$ The graves of those who had passed on can also further our understanding of cultural interactions among the living. ${ }^{3}$ Leonard Victor Rutgers' study of Jewish burials at Rome (second-fourth centuries), for instance, demonstrates this well and finds that instead 'of living in splendid isolation or longing to assimilate, the Roman Jews ... appear as actively and, above all, as self-consciously responding to developments in contemporary non-Jewish society'. ${ }^{4}$ Careful attention to burial customs in other parts of the empire can provide a new vantage point on questions of acculturation and

\footnotetext{
1 I would like to thank those who provided feedback on this paper at several stages, including those at the Canadian Society of Biblical Studies in Winnipeg (2004), at the Hellenistic Judaism section of the SBL in San Antonio (2004), and at Concordia University, Montreal, as well as the anonymous readers and the editors at $J J S$. Research for this paper, including a trip to Hierapolis, was supported by grants from the Fonds québécois de la recherche sur la société et la culture and the Social Sciences and Humanities Research Council of Canada. I would like to thank Prof. Francesco D'Andria, the director of the Italian Archeological Mission at Hierapolis, and the staff at the Hierapolis museum for their permission to examine and photograph monuments. Thanks also go to my research assistant, Angela Brkich, for bibliographical assistance.

2 On Asia Minor, see for example, Paul R. Trebilco, Jewish Communities in Asia Minor (Cambridge: Cambridge University Press, 1991), pp. 167-85; John M. G. Barclay, Jews in the Mediterranean Diaspora from Alexander to Trajan (323 BCE-117 CE) (Edinburgh: T. \& T. Clark, 1996), pp. 259-81, 320-35; Martin Goodman, ed., Jews in the Graeco-Roman World (Oxford: Clarendon, 1998); Tessa Rajak, The Jewish Dialogue with Greece and Rome: Studies in Cultural and Social Interaction (Leiden: Brill, 2002), pp. 335-54, 355-72, 447-62; Philip A. Harland, Associations, Synagogues, and Congregations: Claiming a Place in Ancient Mediterranean Society (Minneapolis: Fortress Press, 2003).

3 On Jewish burial in the diaspora see, for example, P. W. van der Horst, Ancient Jewish Epitaphs: An Introductory Survey of a Millennium of Jewish Funerary Epigraphy (300 BCE-700 $C E$ ) (Contributions to Biblical Exegesis and Theology 2; Kampen, Netherlands: Kok Pharos Publishing House, 1991); Margaret H. Williams, 'The Organization of Jewish Burials in Ancient Rome in the Light of Evidence from Palestine and the Diaspora', ZPE 101 (1994), pp. 165-82; J. H. M. Strubbe, 'Curses Against Violation of the Grave in Jewish Epitaphs of Asia Minor', in Studies in Early Jewish Epigraphy (ed. Jan Willem van Henten and Pieter Willem van der Horst; AGJU 21; Leiden: E. J. Brill, 1994) and APAI EПITYMBIOI: Imprecations Against Desecrators of the Grave in the Greek Epitaphs of Asia Minor. A Catalogue (IGSK 52; Bonn: Rudolf Habelt, 1997); David Noy, 'Where Were the Jews of the Diaspora Buried?', in Jews in the Graeco-Roman World (ed. Martin Goodman; Oxford: Clarendon, 1998), pp. 75-89.

${ }^{4}$ Leonard Victor Rutgers, The Jews in Late Ancient Rome: Evidence of Cultural Interaction in the Roman Diaspora (Leiden: Brill, 1994), p. 263.
} 
identity among minority cultural groups such as Jewish synagogues. ${ }^{5}$

This paper explores cultural interactions in the ancient context with special attention to Jewish epitaphs from Hierapolis in Asia Minor, some of which are newly published by Elena Miranda. ${ }^{6}$ In particular, I focus my attention on the family grave of P. Aelius Glykon and Aurelia Amia (c. 200 CE), recently re-published by Tullia Ritti (formerly $C I J$ 777). ${ }^{7}$ This grave illustrates well the complexity of cultural identities and the potential for interaction between Jews and their neighbours in the cities of Asia Minor. It involves Glykon's bequest to local guilds of purple-dyers and carpet-weavers in order to regularly perform ceremonies at this family grave on Jewish (Passover and Pentecost) and Roman (Kalends) holidays.

Few scholars fully explore this family grave within the framework of burial practices among Jews in Hierapolis and in relation to guild-life in Asia Minor. In looking at this case, I also work to resolve an ongoing debate regarding the composition of the guilds mentioned in the inscription. While several scholars make known their differing views on the identity of these groups (Jewish, nonJewish, or mixed), few sufficiently investigate this issue in relation to other evidence for the purple-dyers at Hierapolis. I conclude with comments on the dynamics of acculturation and assimilation among minority cultural groups in the diaspora.

\section{Jews at Hierapolis}

Recent discoveries of graves have added to our knowledge of Jews at Hierapolis. Miranda's recent publication (1999) includes a total of twenty-three Jewish grave-inscriptions (out of a total of over 360 published epitaphs from Hierapolis), including thirteen new inscriptions beyond those previously published by Walther Judeich (in 1898) and by Fabrizio A. Pennacchietti (in 1966-67). ${ }^{8}$

5 My use of the terms 'assimilation' and 'acculturation' are informed by sociological theories which I discuss at length in the final section of this paper. My use of 'identity' is informed by social-psychological studies of social identity, which use the term in reference to a person's selfconception as a group member, and by anthropological studies on the ascriptive (rather than primordial) nature of ethnic identities specifically (which follow the lead of Fredrik Barth). In both cases, these theories emphasise the complexity and shifting multiplicity of social or cultural identities. For an excellent discussion and bibliography in reference to the ancient context see Philip S. Esler, Conflict and Identity in Romans: The Social Setting of Paul's Letter (Minneapolis: Fortress Press, 2003), pp. 19-76. Cf. Dominic Abrams and Michael A. Hogg, 'An Introduction to the Social Identity Approach', in Social Identity Theory: Constructive and Critical Advances (ed. Abrams and Hogg; New York: Harvester Wheatsheaf, 1990), pp.1-5.

${ }^{6}$ Elena Miranda, 'La comunità giudaica di Hierapolis di Frigia', Epigraphica Anatolica 31 (1999), pp. 109-55 (= IHierapMir); cf. SEG 49 (1999) 1814-1836. Epigraphic abbreviations here largely follow G. H. R. Horsley and John A. L. Lee, 'A Preliminary Checklist of Abbreviations of Greek Epigraphic Volumes', Epigraphica 56 (1994), pp. 129-69. Additionally IJO = Inscriptiones Judaicae Orientis (Tübingen: Mohr Siebeck, 2004), 3 vols.

7 Tullia Ritti, 'Nuovi dati su una nota epigrafe sepolcrale con stefanotico da Hierapolis di Frigia', Scienze dell'antichità storia archeologia antropologia 6-7 (1992-93), pp. 41-68.

8 Those previously published are: IHierapMir $5=I$ IHierapJ $69=$ CIJ 776; no. $6=$ IHierapPenn 14; no. $8=$ IHierapJ $72=$ CIJ 778; no. $9=$ IHierapJ 97; no. $10=$ IHierapJ 104; no. 11 = IHierapPenn 30; no. $16=$ IHierapJ $212=I G R$ IV $834=$ CIJ 775; no. $20=$ IHierapPenn 46; no. 22 = IHierapJ 295; and no. $23=$ IHierapJ $342=C I J$ 777. IHierapJ = Walther Judeich, 
The majority of the Jewish inscriptions (IHierapMir 1-21) are from the northern necropolis, which was extended from the time of Antoninus Pius (138-161 $\mathrm{CE}$ ) and whose monuments date mostly from the middle of the second to the third centuries; ${ }^{9}$ two Jewish tombs were found elsewhere in the area of the eastern burial grounds (IHierapMir 22-23). The Jewish inscriptions range in date from the second half of the second to the third or fourth centuries based on onomastics (especially the presence of Aurelius-related names), and on the forms of the lettering in relation to other dated inscriptions; it is difficult to date them with any more certainty, as none expressly supply a date and rarely are named figures known from other sources.

The majority of these inscriptions (eighteen) involves an individual identified as 'Jewish' / 'Judean' (Ioudaios) making provisions for the burial of him or herself and family members, without explicit reference to a Jewish community. Almost all of these identify the owners of the grave and surrounding area and list other family members that were to be buried there, and several go further in following standard forms of burial inscriptions in this part of Asia Minor by warning that no one else should be buried there and by providing for fines in the event that anyone attempted to do so. ${ }^{10}$ Fines were most often payable to the 'most sacred treasury' (tamion) or, in one case, to the civic 'elders' organisation' (gerousia). ${ }^{11}$ Several of those that specify fines also mention that a copy of the inscription was placed in the civic archives, ${ }^{12}$ which was another important formal institution in the Greek cities of Asia Minor. The act of placing a copy of these stipulations in the civic archives is suggestive of the formal legal procedures that would be followed in the courts of Hierapolis in the event that provisions for care and protection of the grave were violated in some way. ${ }^{13}$

Several inscriptions (three, or perhaps four, of the twenty-three) use terminology suggestive of a group or association of Jews, providing the only information we have about the local synagogue (or perhaps synagogues, over time) at Hierapolis (IHierap Mir 5, 6, 14b, 16). The epitaph which is inscribed with

'Inschriften', in Altertümer von Hierapolis (ed. Carl Humann, et al.; Jahrbuch Des Kaiserlich Deutschen Archäologischen Instituts, Ergänzungsheft 4; Berlin: Georg Reimer, 1898), pp. 67181. IHierapPenn = Fabrizio A. Pennacchietti, 'Nuove iscrizioni di Hierapolis Frigia', Atti della Accademia delle Scienze di Torino: II classe di scienze morale storiche e filologiche 101 (1966-67), pp. 287-328. All twenty-three are also now included, with commentary, in Walter Ameling, Inscriptiones Judaicae Orientis: Band II Kleinasien (TSAJ 99; Tübingen: Mohr Siebeck, 2004) (= IJO II 187-209).

9 Pennacchietti, 'Nuove iscrizioni', pp. 293-94; cf. Ritti, 'Nuovi dati', p. 42.

${ }_{10}$ IHierapMir 1, 2, 4, 7, 8, 9, 10, 18, 19, 21.

11 IHierapMir 1 (gerousia), 2, 4, 7, 8, 9, 10a, 18, 19, 21.

12 IHierapMir 1, 2, 5, 8, 10, 18, 19, 21.

13 On tymbōrychia in Asia Minor see IHierapJ 275, 312 (cf. IIasos 376, 392). IHierapolis 195, which also involves guilds, more directly indicates this legal context in providing a reward (of 800 denaria) for the 'one prosecuting the case (tō ekdikēsanti)' for violation. See also Erich Gerner, 'Tymborychia', Zeitschrift der Savigny-Stiftung für Rechtsgeschichte, Romanistische Abteilung 16 (1941), pp. 230-75, esp. pp. 250-58, and J. H. M. Strubbe, "CCursed be He That Moves My Bones", in Magika Hiera: Ancient Greek Magic and Religion (ed. Christopher A. Faraone and Dirk Obbink; Oxford: Oxford University Press, 1991), p. 48 n. 9. For other Jewish references to the crime see IJO II 146 (Thyatira), 174 (Akmoneia). 
the plural possessive Ioudeōn (sic), '(Grave) of the Jews', alongside the depiction of a menorah and lion likely refers to a family of Jews, rather than an association, but there are three other definite references to an association or group of Jews (see photo in fig. 1; IHierap Mir $6=$ IJO II 187; cf. IHierap Mir $10)$.

Yet, interestingly enough, each of the three epitaphs uses different terminology for the group. In one, a woman and a man explicitly identify themselves as belonging to the 'people (laos) of the Judeans (or Jews)' and make fines for violation of their grave payable to this group (see photo in fig. 2):

The grave and the burial ground beneath it together with the base and the place belong to Aurelia Glykonis, daughter of Ammianos, and her husband Marcus Aurelius Alexander Theophilos, also known as Aphelias, of the people of the Judeans. ${ }^{14}$ They will be buried in it, but it is not lawful for anyone else to be buried in it. If this is violated, the guilty one will pay a fine of 1000 denaria to the people of the Judeans. A copy of this inscription was placed in the archives.

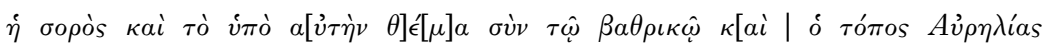

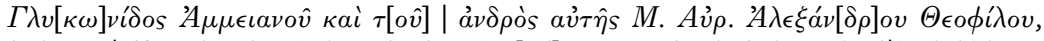

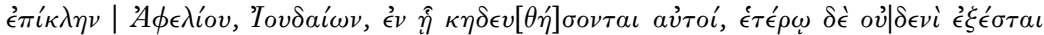

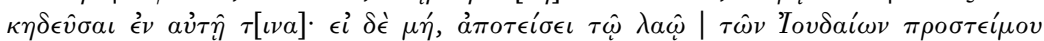

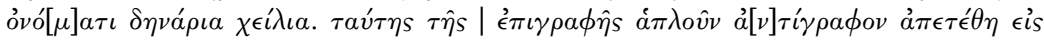
$\tau \dot{a} a \dot{\alpha} \rho \hat{\imath i a}$.

(IHierapMir 5 = IJO II 206; late-second or third century $)^{15}$

The Jewish couple of this epitaph are following the standard form of burial inscriptions at Hierapolis, providing for fines to be paid for violation, in this case to a local association to which they presumably belonged.

A second inscription refers to the 'settlement' (katoikia) of Judeans in Hierapolis:

This grave and the surrounding place belong to Aurelia Augusta, daughter of Zotikos. In it she, her husband, who is called Glykonianos, also known as Hagnos, and their children will be buried. But if anyone else is buried here, the violator will pay a fine of 300 denaria to the settlement of the Judeans who are settled in Hierapolis and 100 denaria to the one who found out about the violation. A copy of this inscription was placed in the archives of the Judeans.

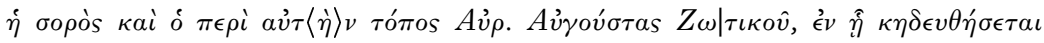

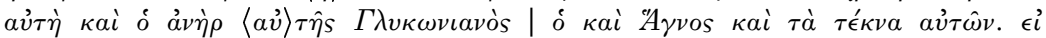

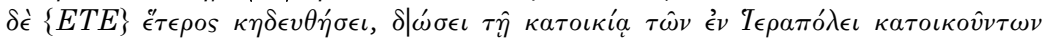

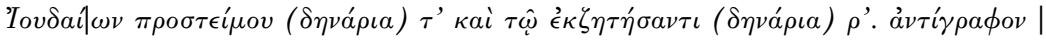

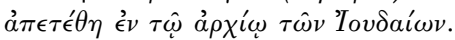

$(\text { IHierapMir } 16=I J O \text { II } 205=C I J 775 \text {; mid-late second century CE })^{16}$

\footnotetext{
14 The designation laos for a group, which seems to be distinctively Jewish in epigraphy (cf. CIJ 662, 699-702, 704-708, 720; ISmyrna 296), is also attested nearby at Nysa, where it is taken as a synonym for synodos (DFSJ $31=I J O$ II 26; now dated to the first century BCE by Ameling, Inscriptiones Judaicae, p. 137).

15 Here and in the following inscriptions I follow Miranda's readings of the text. Miranda suggests the second half of the second century or early third based on the lettering and the onomastics (presence of Aurelia); Ameling suggests second half of the second century.

16 This rough date is once again based on the presence of the gentilicium Aurelius.
} 
Here the group is described with terminology that is commonly used by groups of foreigners or ethnic-based associations in Asia Minor. This is especially well attested in the case of associations of Romans (hoi katoikountes Rómaioi), such as the 'settlement' of Romans that existed at nearby Phrygian Apameia (north-east of Hierapolis) from the first to third centuries, at least. ${ }^{17}$ This suggests that 'Judeans' or 'those from Judea' (in an ethno-geographical and cultural sense) is the best way to translate Ioudaioi in this case. The seemingly redundant 'settlement of Judeans who are settled in Hierapolis' also further suggests this sense of settled immigrants originally from elsewhere. ${ }^{18}$ This inscription also includes the common provision for storage of a copy of the inscription, but in this case this is expressly the archives 'of the Judeans' rather than the civic archives, as was the norm in other Jewish (and non-Jewish) inscriptions. This suggests a well-established Jewish group (by the mid-late second century), such that it would begin to maintain its own archives for a time.

One face (side b) of a third inscription, now published for the first time by Miranda, refers to a group of Jews as 'the most holy synagogue':

(Side a)

The grave, the burial ground beneath it, and the area around it belong to Nikotimos Lykidas, son of Artemisios. In it he has buried Apphia, his wife. A copy of this inscription was placed into the archives. Jewish.

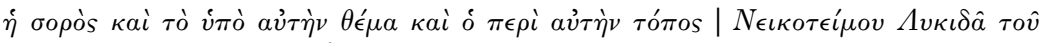

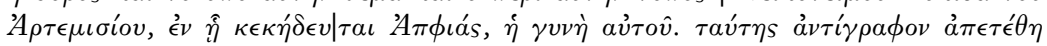

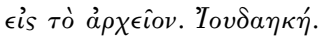

(Side b)

The grave and the place around it belong to Aur. Heortasios Julianus, Tripolitan, Jew / Judean, now living in Hierapolis. In it he and his wife, Glykonis, will be buried, and let their children be buried here as well. It is not lawful for anyone other to be buried in it. If someone does such things, he will pay two silver coins to the most holy synagogue.

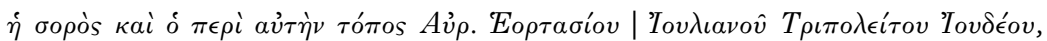

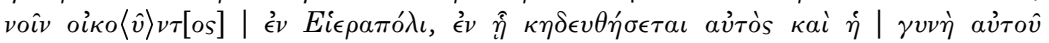

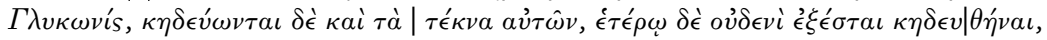

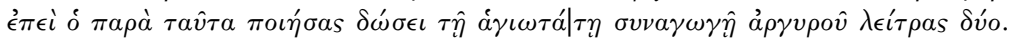

(IHierapMir 14 = IJO II 191; side a, late second century CE; side b, third or

17 IGR IV 785-86, 788-91, 793-94; MAMA VI 177 (c. 65-69 CE), 183. Cf. CIG 2287 (Athenians on Delos) and $O G I S 595=C I G 5853$ (Tyrian merchants at Puteoli).

18 On debates regarding possible geographical meanings of Ioudaioi, which sometimes centre on the 'hoi pote Ioudaioi' inscription from Smyrna (ISmyrna $697=C I J 742)$ see, on the one hand, Margaret H. Williams, 'The Meaning and Function of Ioudaios in Graeco-Roman Inscriptions', ZPE 116 (1997), pp. 249-62 (for the non-geographical, apostasy theory) and, on the other, A. T. Kraabel, 'The Roman Diaspora: Six Questionable Assumptions', JJS 33 (1982), p. 455; Ross S. Kraemer, 'On the Meaning of the Term 'Jew' in Greco-Roman Inscriptions', HTR 82 (1989), pp. 35-53; Harland, Associations, pp. 202-203; and, Philip A. Harland, 'Spheres of Contention, Claims of Pre-Eminence: Rivalries Among Associations in Sardis and Smyrna', in Religious Rivalries and the Struggle for Success in Sardis and Smyrna (ed. Richard S. Ascough; Waterloo: Wilfrid Laurier University Press, 2005), pp. 260-61, note 7 (for the ethno-geographical interpretation). 
fourth century CE) $)^{19}$

The earlier of the two sides of the monument (side a) mentions only that the family members buried there were 'Jewish', and does not mention a community. The reverse of the original inscription (side b) pertains to a family of Jews whose relation to those buried earlier is unclear. They were previous inhabitants, or perhaps citizens, of nearby Tripolis and they assign any potential fines to 'the most holy synagogue'. 20

Overall, then, the evidence from Hierapolis indicates that there was a notable number of Jews living in the city in the period from the mid-second to third or fourth centuries who openly identified themselves as such on their family tombs. Through the accidents of survival and discovery, we happen to encounter about twenty or so families who felt it was important to express Jewish aspects of their identities in this way (two of them decorating their graves with a menorah or other related symbols). There was at least one ongoing gathering or association of Jews, though few families chose to mention such an association on their epitaphs. By the late second century, an association of Jews was well-organised enough to have its own archives. Yet many of the known Jewish epitaphs seem to follow local custom in having copies of the inscription placed in, and/or fines for violation payable to, civic institutions of Hierapolis.

\section{The Family Tomb of P. Aelius Glykon and Aurelia Amia}

One epitaph at Hierapolis does not explicitly use the term 'Judean / Jew (Ioudaios)', nor does it refer to an established Jewish association. Instead, it clearly indicates Jewish connections by referring to holy days, or festivals. The family grave of P. Aelius Glykon and Aurelia Amia dates to the late-second or early-third century of our era, based on the wife's family name, Aurelia, and the forms of the lettering (see fig. 3). ${ }^{21}$ This is a limestone sarcophagus (with a partially damaged lid) inscribed on its long side (facing north-west), which is located in the south-eastern necropolis of Hierapolis near the remains of the Martyrium of St Philip, with no other surviving graves in its immediate vicinity. ${ }^{22}$ Tullia Ritti's re-discovery and thorough new reading of the inscrip-

\footnotetext{
19 Miranda's ('La communità', p. 125) dating depends primarily on the forms of the lettering in relation to other dated monuments at Hierapolis. Ameling (p. 408) suggests that side b may date from the fourth century based on the use of litra, which Louis Robert suggested was characteristic of the fourth and fifth centuries (Robert, 'Un corpus des inscriptions juives,' Hellenica 3 (1946), p. 106).

20 The descriptive term 'most holy' (hagiotat-) and its synonyms are common self-designations among associations and civic bodies in Asia Minor and in Hierapolis specifically (cf. IHierapJ 40, 41, 342; IHierapPenn 25). Although likely the local Tripolis (cf. IHierapPenn 22), there are known cities of the same name in Pontus, in Syria, and in North Africa. Cf. Harry J. Leon, The Jews of Ancient Rome (2nd ed.; Peabody: Hendrickson Publishers, 1995; 1960), pp. 153-54, 240, on the Tripolitan synagogue at Rome.

${ }^{21}$ Cf. Ritti, 'Nuovi dati', p. 48; Miranda, 'La comunità giudaica', p. 132; Ameling, Inscriptiones Judaicae, p. 416

22 Measurements: Bottom: approx. $239 \mathrm{~cm}$ long, $93 \mathrm{~cm}$ tall, and $135 \mathrm{~cm}$ wide. Lid: $74 \mathrm{~cm}$ tall at its high-point. Lettering: approx. $4 \mathrm{~cm}$. The sarcophagus is located at the beginning point of the main gap between two hills near where the main walk-way to the Martyrium of St Philip (now) ends and the staircase ascending to the martyrium begins.
} 
tion, which was first inadequately published in 1868, has significantly filled in previously gaps, including the important reference to the feast of Kalends in lines 9-10 and to the name of Glykon's wife. ${ }^{23}$

The inscription provides important evidence regarding the complexity of cultural identities and the nature of Jewish interactions with others in the Greek city, and reads as follows:

This grave and the burial ground beneath it together with the surrounding place belong to Publius Aelius Glykon Zeuxianos Aelianus ${ }^{24}$ and to Aurelia Amia, daughter of Amianos Seleukos. In it he will bury himself, his wife, and his children, but no one else is permitted to be buried here. He left behind 200 denaria for the grave-crowning ceremony to the most holy presidency of the purpledyers, so that it would produce from the interest enough for each to take a share in the seventh month during the festival of Unleavened Bread. Likewise he also left behind 150 denaria for the grave-crowning ceremony to the association of carpet-weavers, so that the revenues from the interest should be distributed, half during the festival of Kalends on eighth day of the fourth month and half during the festival of Pentecost. A copy of this inscription was put into the archives.

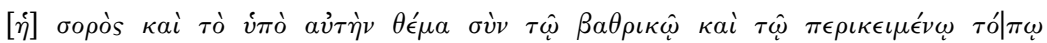

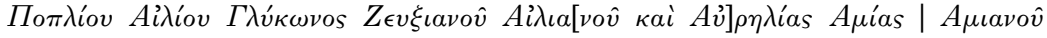

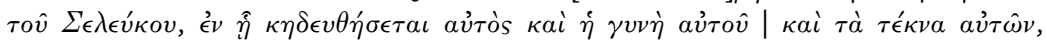

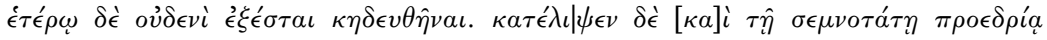

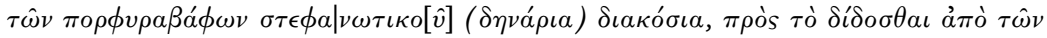

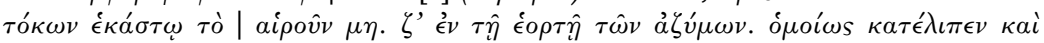

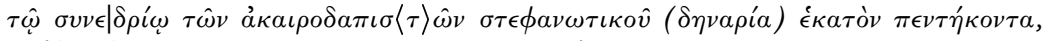

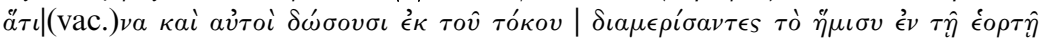

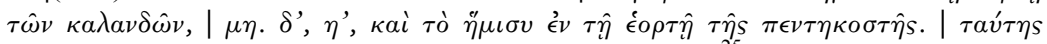

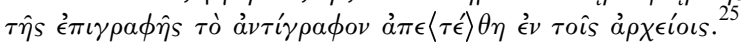

\section{Jewish facets of identity}

The request that customary grave-ceremonies be held on two Jewish holidays clearly points to this family's identification with Judaism. Glykon has

23 Previously partial or undocumented were what is now line 1 , much of line 2, lines 9-10, part of line 11, and line 13. For a list of publications of the original reading $(=C I J 777)$, which followed and corrected A. Wagener, 'Inscription grecque inédite', Revue de l'instruction publique en Belgique 11 (1868), pp. 1 (reproduced in 'Auszüge aus schriften und berichten der gelehrten gesellschaften so wie aus zeitschriften', Philologus 32 (1873), pp. 379-80.), see Ritti, 'Nuovi dati' or Miranda, 'La comunità giudaica', pp. 131-32, no. 23.

New reading: Ritti, 'Nuovi dati'; AE (1994) 1660; SEG 46 (1996) 1656; Guy Labarre and M.Th. Le Dinahet, 'Les metiers du textile en Asie Mineure de l'epoque hellenistique a l'epoque imperiale', in Aspects de l'artisanat due textile dans le monde Mediterraneen (Egypte, Grece, monde romain) (Collection de l'Institut d'Archeologie et d'Histoire de l'Antiquite, Université LumiereLyon 2; Paris: De Boccard, 1996), pp. 102-103, no. 62; E. Miranda, Le iscrizioni giudaiche di Hierapolis di Frigia (Napoli, 1999), pp. 58-59, no. 23 and 'La comunità giudaica', pp. 131-32, no. 23; Imogen Dittmann-Schöne, Die Berufsvereine in den Städten des kaiserzeitlichen Kleinasiens (Theorie und Forschung 690; Regensburg: Roderer Verlag, 2000), pp. 226-27, no. V.5.10; IJO II 196 (Ameling).

24 Or, possibly: 'P Aelius Glykon, son of Zeuxis Aelianus' (cf. Ameling, Inscriptiones Judaicae, p. 416).

25 Ritti, 'Nuovi dati' $=A E$ (1994) 510, no. $1660=$ IHierapMir $23=I J O$ II 196, revising $C I J$ 777. 
consciously made a decision that his death (and that of his family members) be commemorated indefinitely on the feasts of Unleavened Bread (in the month of Nisan, i.e. March-April) and on Pentecost (the spring harvest festival), two of the most important Jewish festivals. ${ }^{26}$ The inscription nowhere identifies the owner (Glykon) as Ioudaios, as do other Jewish epitaphs at Hierapolis, but this would be unnecessary in light of the explicit mention of Jewish holy days. ${ }^{27}$

There is the question, then, of whether Glykon and his family were (born) Jews or whether they were gentiles who adopted important Jewish practices ('judaisers') and then arranged that others (guilds) also engaged in these practices after their deaths. It seems probable, in my view, that Glykon was Jewish based on the primary concern that Jewish festivals be celebrated in connection with the family grave, as most who discuss the inscription also suggest. As Ritti notes, seemingly 'non-Jewish' elements in the inscription which entail local or Roman practices, including the grave-crowning ceremonies and the celebration of the Roman New Year, can readily be understood within the framework of a Jewish family well-adapted to life in Greco-Roman Hierapolis. ${ }^{28}$

This is not to discount the possibility that Glykon and his family were gentiles with a significant level of involvement in Jewish practices, along the lines of the 'god-fearers' in Aphrodisias in the fourth century (IJO II 14). ${ }^{29}$ In the event that Glykon was a gentile adopting Jewish practices and then arranging for others to participate in some way in the Jewish festivals, then we would be witnessing strong signs of acculturation to Jewish ways on the part of a non-Jew rather than acculturation of Jews to local or Greco-Roman ways. ${ }^{30}$ The problem is that, unlike the case of the god-fearers at Aphrodisias, nothing in the Glykon inscription itself provides a basis for building a solid case that Glykon or his family was gentile rather than Jewish. ${ }^{31}$ As we shall see, although there is no clear evidence that Glykon was a gentile, there is indeed corroborating evidence that some members of the purple-dyers' guild

${ }^{26}$ On Jewish festivals in the diaspora see Barclay, Jews, pp. 415-16. Cf. Josephus, Ant. 14.25658 and 16.45; Joyce Reynolds, 'Inscriptions,' in Excavations at Sidi Khrebish Benghazi (Berenice), volume I: Buildings, Coins, Inscriptions, Architectural Decoration (ed. J. A. Lloyd; Supplements to Libya Antiqua 5; Libya: Department of Antiquities, Ministry of Teaching and Education, People's Socialist Libyan Arab Jamahiriya, 1977), pp. 244-45, no. 17 (feast of Tabernacles at Berenike, Cyrenaica c. 24 CE).

27 Cf. Ritti, 'Nuovi dati', p. 59.

28 Ritti, 'Nuovi dati', pp. 59-60.

29 On the fourth- or fifth-century dating, now see Angelos Chaniotis, 'The Jews of Aphrodisias: New Evidence and Old Problems', Scripta Classica Israelica 21 (2002), pp. 209-42.

30 On possible cases of gentile judaising in Asia Minor and Syria based on Christian literary evidence, see Michele Murray, Playing a Jewish Game: Gentile Judaizing in the First and Second Centuries CE (ESCJ, vol. 13; Waterloo: Wilfrid Laurier University Press).

31 On the difficulties of identifying some inscriptions as Jewish, Christian, or pagan, and of finding gentile sympathisers in particular see Kraemer, 'On the Meaning of the Term "Jew"'; Williams, 'Meaning and Function'; Ameling, Inscriptiones Judaicae, pp. 16-20. Miranda ('La comunità giudaica', pp. 144-45) is attracted by the hypothesis that Glykon was a 'Jewish sympathiser' but admits the difficulties here. Also see the discussion of the purple-dyers and the Aphrodisias material further below. 
mentioned in this inscription were gentiles. The discussion here explores the multiple and intertwined facets of identity in the case of this family and the purple-dyers' guild, returning in the conclusion to the implications for acculturation depending on whether Glykon was a Jew or a gentile judaiser.

\section{Roman facets of identity and the feast of Kalends}

Alongside this family's clear identification with Judaism are various signs of intertwined Hierapolitan, Hellenistic, and Roman elements, which I explore throughout this paper. As recent studies of the diaspora stress, Jewish identities were by no means incompatible with a sense of belonging within the Greco-Roman world. Before considering indications of assimilation to local cultural life in Hierapolis, which inevitably also involves intertwined Roman elements, it is important to note some clear signs of this family's Roman identity specifically.

First, P. Aelius Glykon's name indicates that he is a Roman citizen. If the inscription pre-dates or immediately follows the universal grant of citizenship in 212 CE (Constitutio Antoniniana), as most suggest, then Glykon's choice to include his tria nomina indicates some sense of pride in possessing the status of Roman citizen. ${ }^{32}$ It is possible that Glykon or his ancestors were formerly slaves who gained Roman citizenship upon manumission, though there is nothing in the inscription or from other sources relating to Hierapolis that would confirm that. With regard to this man's cognomen, it is worth mentioning that personal names with the root Glyk- ('sweet') are very common in Hierapolis and Phrygia generally, and that this was likewise quite common among Jews at Hierapolis. ${ }^{33}$ So even this man's name indicates Roman and Hierapolitan dimensions of his identity.

Beyond Roman citizenship, we lack clear indications of Glykon's socialeconomic status within Hierapolis. Still, it is worth mentioning that most monuments in which a family provides a foundation to a local association or guild to perform grave ceremonies, the deceased (or deceased-to-be) was a Roman citizen with some degree of wealth (compare section four below on the grave-crowning ceremony). Glykon's total amount of 350 denaria (200 plus 150) for the grave-crowning ceremonies (stephanottikon) is greater than, yet comparable to, the case of Aurelius Zotikos Epikratos, who gave 150 denaria to the guild of nail-workers (IHierapJ 133). On the other hand, Glykon's foundation is less than Publius Aelius Hermogenes' substantial grant of 1000 denaria to the guild of dyers (IHierapJ 195). Tiberius Claudius Kleon, whose position as high-priest (archiereus) suggests he is among the civic elites, ${ }^{34}$

\footnotetext{
32 Of the twenty-three Jewish epitaphs at Hierapolis, sixteen (including the Glykon inscription) provide a name which suggests Roman citizenship and five of these are dated to the post212 CE era by Miranda. Eleven are potentially cases of Jews with Roman citizenship before the universal grant (mainly in the late-II or early-III CE).

${ }^{33}$ See IHierapMir 5, 11, 14, and 16 (cited earlier). See Miranda's discussion of onomastics among Jews at Hierapolis ('La comunità giudaica', pp. 136-40).

34 Compare the high-priest Tiberius Claudius Zotikos Boa, who also held other important civic offices or liturgies including strategos, agonothetēs, and presbeutēs. He was honoured by both the 'most sacred guild of wool-cleaners' and the 'most sacred guild of purple-dyers' on two separate monuments (IHierapJ 40, 41; probably third century).
} 
donated the largest attested amount for the grave-crowning ceremony at Hierapolis, granting the sum 2500 denaria to the civic elders' organisation (gerousia; IHierapJ 234). So Glykon is among many other Roman citizens, some of higher and others of lower social-economic or civic status, at Hierapolis, but we do not know whether he was a citizen and, if so, whether we can consider him among the civic elites who assumed important offices.

A second, more significant sign of the adoption of things Roman has been revealed only with the new edition of the epitaph. Glykon chooses to have his family remembered not only on principal Jewish holidays, but also on the feast of Kalends, the Roman New Year celebration (held in January). Glykon leaves funds (150 denaria) to the association of carpet-weavers, specifying that half of the proceeds from the foundation be used during the feast of Kalends (and half during Pentecost).

It is important to say a few words regarding this Roman New Year festival to assess its significance here at Hierapolis. The sparseness of our evidence for the celebration of this particular Roman festival in Asia Minor makes the Glykon inscription all the more relevant to issues of Romanisation. ${ }^{35}$ Michel Meslin's study of the festival emphasises two complementary dimensions: the official ('civic') and the unofficial ('private'). ${ }^{36}$ The official side of the festival was focused on vows for the well-being of Rome and its empire as one year ended and the new began. Pliny the Younger provides some limited evidence that this aspect of the festival was celebrated in northern Asia Minor by the early second century (Pliny, Ep. 10.35-36, 100-101; cf. Suetonius, Nero 46.4). The Glykon inscription now confirms the continuing adoption of this festival in another area of Asia Minor a number of decades later.

There were also unofficial dimensions to the Roman New Year festival, which would likely be of greater relevance to the situation within a local guild at Hierapolis. These informal celebrations were 'anchored in the collective psyche of the Romans' and charged with social and religious significance, as Meslin puts it. ${ }^{37}$ Although the festival originally focused its attention on the old Italian god Janus (two-faced protector of doors), its significance expanded beyond this focus. Ovid's famous poetic tribute to the Roman festivals (the Fasti), written in honour of Augustus, emphasises the exchanges of 'good wishes' and gifts which accompanied the celebration, including 'sweet' gifts (e.g. dates, figs, honey), as well as cash, indicating an omen of a sweet year to come (Fasti 1.171-194). Ovid also alludes to the common practice of work-

\footnotetext{
35 While evidence for the celebration of the Roman New Year festival (in January) in Asia Minor is partial at best, we do know that, beginning in about 9 BCE and continuing at least into the second century, new year's celebrations were held in the province of Roman Asia on the birthday of Augustus (September 23), and associations were sometimes involved in those celebrations (IPergamon 374; and IEph 3801). See S. R. F. Price, Rituals and Power: The Roman Imperial Cult in Asia Minor (Cambridge: Cambridge University Press, 1984), pp. 54-55; Harland, Associations, pp. 94-95, 102.

${ }^{36}$ For the following see: Meslin La fête des kalendes de janvier dans l'empire romain (Collection Latomus 115; Brusselles: Latomus Revue d'Études Latines, 1970), pp. 23-50; and, M. P. Nilsson 'Studien zur Vorgeschichte des Weihnachtsfestes', Archiv für Religionswissenschaft 19 (1916-19), pp. 54-55, who also notes the involvement of collegia in the celebrations.

37 Meslin, La fête, p. 23 (trans. mine).
} 
ers dedicating their occupational activities in connection with the commencement of the new year (Fasti 1.169-70), which may be of relevance to workers such as the carpet-weavers at Hierapolis. A statement by Herodian, a third century Greek historian, confirms the importance of 'exchanging friendly greetings and giving each other the pleasure of interchanging gifts' (History 1.16.2). If Tertullian's negative assessment of Christians' participation in New Year's gift-giving as 'idolatry' is any indication, the exchange of gifts (strenae) specifically remained prominent as the festival made its way into the provinces, at least in regions like North Africa around the turn of the third century. ${ }^{38}$

It is likely these social aspects of celebrating the end of the old year and the beginning of the new, exchanging positive wishes and gifts, remained the focus of attention in many contexts, including this case at Hierapolis. Not surprisingly, diaspora Jewish attitudes and practices in relation to such festivals could extend beyond the views expressed in rabbinic sources (in the Abodah Zarah tractates), which simply assume that Jews should distance themselves from any relation to major gentile festivals, including Kalends specifically. ${ }^{39}$

\section{Funerary practices and associations in Roman Asia}

The nature of this family's participation in local cultural practices can be better understood in relation to other Jews in the city and in relation to other (non-Jewish) Hierapolitans who involved guilds in funerary provisions. Glykon's choice to include guilds in funerary commemorations on Jewish and Roman festivals excluded - whether incidentally or not - the local Jewish association from any direct relation to the burial and upkeep of the family grave. Glykon was certainly not alone in failing to even mention the local synagogue (with which he likely associated) on his epitaph, however, as many other known Jewish and non-Jewish epitaphs make no mention of any local group or synagogue with which the family was affiliated.

A discussion of funerary involvements among associations (including Jewish groups) in western Asia Minor will provide important context here, pointing toward common burial customs shared by Jews (or possibly gentile Judaisers) such as Glykon and his family. ${ }^{40}$ There were three main ways in which

38 Tertullian, On Idolatry 10 and 14; cf. On Military Crowns 12.3; Apology 35.7. On gifts (strenae) see Suetonius, Augustus 57, Tiberius 34, Caligula 42.

39 Cf. M. Hadas-Lebel, 'Le paganisme à travers les sources rabbiniques des IIe et IIIe siècles. Contribution a l'étude du syncrétisme dans l'empire romain', $A N R W$ II.19.2 (1979), pp. 426441. Some debates about contact with gentiles are reflected in a story of a gentile Roman official (quaestor) who, in celebration of the Roman New Year, honoured Yudan the patriarch with a gift of a chest of coins. The rabbi accepted only one of the coins and sent back the chest (presumably to avoid offence and to recognise the generosity of the gift-giver), but another rabbi was of the opinion that it was prohibited to benefit from even that one coin (yAbod. Zar. 1.1, II.E). A tradition in both Talmuds suggests that Adam founded the festival of Kalends and observed eight days of festivities, but he did so for the 'sake of heaven' while the pagans established a corresponding festival for 'idolatry' (bAbod. Zar. 1.3).

40 On funerary practices in Asia Minor generally see, most recently: Strubbe, 'Cursed', 'Curses Against Violation', and APAI EIITYMBIOI. On the role of associations in the Greek East see, for example, Onno M. van Nijf, The Civic World of Professional Associations in the Roman East 
guilds and other associations participated in grave-related activities. First, associations could play a role in the burial of their members, sometimes collecting ongoing fees for later use in funerary related expenses (actual burial or funerary banquets, for instance) ${ }^{41}$ Local custom varied in the details and in the importance of this role, however. There is limited evidence that associations in some regions of Asia Minor might also have their own group burial plot or collective tomb for this purpose. This was the case with the guild of flax-workers at Smyrna, who received a vault as a donation, and the guild of bed-builders at Ephesos, who dedicated a common burial plot. ${ }^{42}$ As with associations generally, it seems that collective burial by association was not the norm among synagogues in the diaspora; instead, the shared family tomb was standard among both Jews and non-Jews (including those who happened to belong to an association). Still, there is one clear example from Tlos (in Lycia) in which a man named Ptolemais adopts this (local, Tlosian) practice by preparing a common burial area (hêrōon) for his son and for 'all the Jews' (first century CE). ${ }^{43}$ Having noted this role of associations in the burial of individual members and a few cases of common burial by association, it is important to point out that there are many epitaphs that simply do not refer to such groups at all. So the Jews at Hierapolis who failed to mention any affiliation with a Jewish association or who did not involve a local guild in funerary arrangements there are not out of the ordinary in this respect.

A second funerary role involves associations being named as recipients of fines for any violation of the grave alongside other civic institutions (e.g. civic treasury, council, people, elders' organisation), or alone. Several guilds at Kyzikos are designated as recipients of any fines for violation of the grave, for instance, and a similar picture emerges at Smyrna, where two different families chose an association of porters who worked in the harbour. ${ }^{44}$ So in some ways the 'head of the synagogue' at Smyrna in the second or third century (a woman named Rufina) was following local custom when she made fines for violation of her household's grave payable to the 'most sacred trea-

(Dutch Monographs on Ancient History and Archaeology 17; Amsterdam: J. C. Gieben, 1997), pp. 31-69, and Imogen Dittmann-Schöne, Die Berufsvereine. pp. 82-93.

41 Cf. Artemidoros, Oneir. 5.82.

42 ISmyrna 218; IEph 2213; cf. IEph 2213; IKilikiaBM II 190-202; IKosPH 155-59; P. M. Fraser, Rhodian Funerary Monuments (Oxford: Clarendon Press, 1977), pp. 58-70. Also see van Nijf, Civic World, pp. 43-49.

43 IJO II $223=$ CIJ $757=T A M$ II 612 . This inscription from Tlos plays a role in a recent debate regarding how common were such collective 'Jewish cemeteries' in the first two centuries (before the catacombs of Rome). Strubbe ('Curses Against Violation', pp. 101-102) draws on the clear Tlos case to argue for the commonality of collective Jewish grave plots in Asia Minor (using other less certain evidence along the way). On the other hand, David Noy ('Where Were the Jews of the Diaspora Buried?', p. 81) argues that 'the existence of separate Jewish burial areas before the catacombs seems on the whole fairly unlikely'. I would suggest that forms of Jewish burial would be dependent on variations in local practice among associations, and, in fact, at least two epitaphs from Tlos appear to confirm this point. Like the Jewish epitaph, they involve a collective burial area (hèrōon). Each lists names (with no mention of familial relation among the names) of those who are to be buried within it, likely the members of associations (TAM II 604 and 615).

44 IKyzikos 97, 211, 291 (marble-workers, clothing-cleaners, and porters); ISmyrna 204, 205; cf. IAlexTroas 122 (coppersmiths, II CE), 151-52 (porters). 
sury' of Smyrna (1500 denaria) and to an association (1000 denaria), in this case the ethnos of the Jews of which she was a leader or benefactor. ${ }^{45}$

A third area of funerary involvement on the part of associations in Asia Minor entails groups being designated recipients of a foundation that made them responsible for visiting and maintaining the grave, including yearly (or more frequent) ceremonies at the site. ${ }^{46}$ It was not necessarily the case that the owner of the grave was a member of the association in question. ${ }^{47} \mathrm{It}$ seems that the more important factor in decision-making (on the part of the deceased-to-be or family members of the deceased) concerned choosing a group that could indeed be trusted to help protect the grave and fulfill other obligations, and sometimes this was a group to which a family member belonged.

Several inscriptions from Ephesos illustrate this function of associations, for instance. In one first century epitaph, a silversmith and his wife designate the association (synedrion) of silversmiths as recipient for any fines, but they also leave behind specific funds so that the group can 'take care of' (kēdetai) the grave-site (IEph 2212) ${ }^{48}$ In another, a physician and his wife leave behind an endowment for the "association (synedrion) of physicians in Ephesos who meet in the "museum" (mouseion)' to take care of the grave (IEph 2304). Quite interesting for our present purposes is the family epitaph of a chief-physician at Ephesos (named Julius), who asked that 'the Jews in Ephesos' (not the synedrion of physicians) maintain the tomb. ${ }^{49} \mathrm{It}$ is unclear as to whether Julius was a Jew or not, but either way we are seeing Jews participating in local customs in places like Ephesos.

Along similar lines, a devotee of the Jewish God (either a Jew or a Christian) in third-century Akmoneia donated several tools to 'the neighbourhood of those near the first gateway' (IJO II 171). ${ }^{50} \mathrm{He}$ did so on the condition that

45 ISmyrna $295=$ IJO II $43=$ CIJ 741. Cf. IJO II 154, 157 (Nikomedia, III CE).

46 On grave visitation, see Robert Garland, The Greek Way of Death (2nd ed.; Ithaca: Cornell University Press, 2001), pp. 104-120. On Roman burial practices, see J. M. C. Toynbee, Death and Burial in the Roman World (London: Thames and Hudson, 1971), pp. 61-64. On crowns, see E. R. Goodenough, Jewish Symbols in the Greco-Roman Period (New York: Pantheon Books, 1953-68), vol. 7, pp. 148-71.

47 Thus, for instance, Aurelius Zotikos Epikratos made arrangements for the guild of nailworkers to perform the grave-crowning ceremony. The fact that the deceased was not a member of that guild is suggested by the fact that two other guilds (copper-smiths and purple-dyers) are listed as back-ups if the nail-workers failed to fulfill their obligations (IHierapJ 133; cf. IHierapJ 227).

48 Cf. IEph 2402 (potters), 2446 (linen-workers).

49 IEph $1677=$ IJO II $32=$ CIJ 745; II CE. See IJudEur I 76 from Venosa for another Jewish chief-physician.

50 The inscription uses the so-called Eumeneian formula, which stipulates that if someone violates arrangements on the epitaph they will have 'to reckon with the justice of God' (estai autō pros ton theon). Ramsay and others felt that the inscription was Christian, assuming the Eumeneian formula was exclusively Christian, which is now known to be used by Jews also (Ramsay, The Cities and Bishoprics of Phrygia, Oxford: Clarendon Press, 1895-97, p. 520). Louis Robert thought that the owner of the grave was probably Jewish, based on the 'Semitic' name of the man (Math(i)os) who sold the plot to Aur. Aristeas (assuming that they were 'co-religionists') and on the absence of other evidence of Christians in third-century Akmoneia (Louis Robert, 'Épitaphes juives d'Éphèse et de Nicomédie', Hellenica 11-12 (1960), pp. 409-12; cf. Trebilco, 
this neighbourhood-association yearly decorated his wife's grave with roses (rodisai), performing the Roman ceremony of rosalia, which would have most likely included a banquet. ${ }^{51}$ This offers an interesting parallel to Glykon's request to have grave-crowning ceremonies held on the Roman New Year, led by the carpet-weavers' association. ${ }^{52}$ In both cases a traditionally Roman festival is adapted to local custom (involving associations) by families devoted to the Jewish God, presumably omitting practices that would evoke honours for Greco-Roman deities (namely, sacrifice).

\section{Guilds at Hierapolis and the identities of the purple-dyers}

Turning to Hierapolis specifically, it is important to give some sense of what role the guilds played in funerary practices there, which will then shed more light on the significance of Glykon's decision to include guilds (and the purple-dyers in particular) in his bequest. Of the sixteen extant inscriptions that refer to occupational associations at Hierapolis, ten are epitaphs, and six of these expressly involve a guild or guilds in some ongoing grave ceremonies or superintendence of the grave (including the Glykon inscription). Most of these (four) involve the local practice of providing 'funds for the grave-crowning' (stephanotikon), which in this form of expression seems peculiar to the Lycos valley, primarily Hierapolis. ${ }^{53}$ Another refers to the responsibility of a guild (purple-dyers or, if they fail, the livestock-dealers) in 'burning the incense (papoi) on the customary day' (IHierapJ 227b; c. 190-250 CE). Furthermore, five of the ten epitaphs also mention guilds as recipients of any fines for violation of the grave. ${ }^{54}$

Since there are cases where several guilds are involved on one epitaph, in all there are a total of ten guilds mentioned in connection with funerary arrangements in the extant monuments of Hierapolis: dyers, nail-workers, copper-smiths, purple-dyers, livestock-dealers, water-mill engineers, farmers, wool-cleaners, carpet-weavers, and an unknown 'guild'. The association of purple-dyers, in particular, stand out prominently as a favourite in the fu-

Jewish Communities, pp. 78-80; Strubbe, 'Curses Against Violation', pp. 72-73). The arguments for Jewish identity are less than certain, and either option (Jewish or Christian) remains a possibility here. For Jews at Akmoneia see IJO II 168-78. For Christians see MAMA VI 336.

51 On associations and the rosalia festival in the Greek East, see $I G$ X.2 260; IMakedD 920; CIL III 703, 704, 707 (from Macedonia); IPergamon 374B; CIG 3874; IKlaudiupolis 115; INikaia 62, 95, 1283, 1422; SEG 49 (1999) 1790 and 2508 (from Asia Minor). Cf. Paul Perdrizet, 'Inscriptions de Philippes', BCH 24 (1900), pp. 299-323; Trebilco, Jewish Communities, pp. 80-81. On collegia in the Latin West see Toynbee, Death and Burial, pp. 61-64; Richard Alexander Lattimore, Themes in Greek and Latin Epitaphs (Urbana: University of Illinois Press, 1962), pp. 137-41 (cf. CIL V 2090, 2176, 2315, 4015, 4017, 4448).

52 On the use of crown symbolism in Jewish art, architecture, and literature, see Goodenough, Jewish Symbols, vol. 7, pp. 149-52. For Jewish adaptation of granting crowns as a form of honour for living benefactors see IJO II 36 (Phokaia or Kyme; III CE) and Philippe Bruneau, "Les Israélites de Délos" et la juiverie Délienne', BCH 106 (1982), pp. 465-504; NewDocs VIII 12 (Samaritans on Delos; c. II-I BCE).

53 IHierapJ 50, 195; IHierapPenn 45; IHierapMir $23=$ IHierapJ 342. On this local ceremony see Judeich's notes to IHierapJ 195, as well as IHierapJ 133, 153, 209, 234, 270, 278, 293, 310, 336 (cf. ILaodikeia 84, 85).

54 IHierapJ 218; IHierapPenn 7, 23, 25, 45. 
nerary monuments that have survived to us, appearing as recipients of fines or bequests for visitation ceremonies on nearly half (four out of ten) of the grave-inscriptions involving guilds, including the Glykon family grave itself. ${ }^{55}$

The fact that a family devoted to the Jewish God specifically chose to call on the services of the purple-dyers, as well as the carpet-weavers (known only from the Glykon inscription), begs a question regarding the composition or ethnic identities of the membership of these guilds. This issue is important in evaluating the possibilities regarding dynamics of assimilation or interaction that we are witnessing. Scholarly discussions of this inscription, including many based on the earlier reading which lacked the reference to Kalends, address the question of whether the guilds were (1) solely Jewish, (2) solely gentile ('pagan'), or (3) a mixture of both, but seldom with reference to other epigraphical evidence for the purple-dyers. Such evidence shows that, for the purple-dyers, at least, the first option is untenable, the second plausible, and the third most likely.

Erich Ziebarth was among the first to suggest that these two guilds were solely Jewish in membership, and other scholars have followed suit, including William Ramsay and Shimon Applebaum. ${ }^{56}$ Most recently, Miranda suggests that the purple-dyers, at least, were solely Jewish, based on the fact that Glykon chose to have the purple-dyers provide their services only on a Jewish holiday, whereas the bequest to the carpet-weavers involves both a Roman and a Jewish holiday, reflecting Glykon's choice of separate holidays for the gentile and Jewish members of that mixed group, in her view. ${ }^{57}$ However, the Glykon inscription does not give any clear indication that either of these guilds were distinctively Jewish, nor that they stood out from other such groups in Hierapolis.

More importantly, numerous inscriptions (seven in all) concerning purpledyers in this period (mid-second to early-third centuries) show that, rather than being distinctively Jewish, this guild consisted principally of gentiles (at the points we have any evidence for them) and were viewed as a typical guild in the city. ${ }^{58}$ Thus, for instance, the purple-dyers (he techné tōn porphyraba[phōn]) joined with the polis in about $209 \mathrm{CE}$ to dedicate a por-

55 IHierapJ 133, 227; IHierapPenn 23 and IHierap Mir 23 = IHierapJ 342.

56 Ziebarth, Das griechische Vereinswesen (Stuttgart: S. Hirzel, 1896), p. 129; Ramsay, 'Antiquities of Hierapolis (Humann, Cichorius, Judeich, Winter)', Classical Review 14 (1900), p. 81, and 'The Jews in the Graeco-Asiatic Cities', Expositor 5 (1902), pp. 98-101; Applebaum, 'The Organization of the Jewish Communities in the Diaspora', in The Jewish People in the First Century: Historical Geography, Political History, Social, Cultural and Religious Life and Institutions (ed. S. Safrai and M. Stern; Compendia Rerum Iudaicarum Ad Novum Testamentum 1; Assen: Van Gorcum, 1974), pp. 480-83.

57 Miranda, 'La comunità giudaica', pp. 140-45.

${ }^{58}$ Cf. Judeich 'Inschriften', p. 174; Ritti, 'Nuovi dati', pp. 66-67. There are slight variations in the terminology used in reference to the purple-dyers (see note 60), but it would be problematic to argue that more than one guild of purple-dyers existed at one time based on such slight changes, since such variations (rather than strict titles) were common among other associations and terms such as 'most holy' or 'most sacred' often appear when the group in question (rather than someone else) was in charge of having the monument inscribed (cf. note 20). The purple-dyers are to be distinguished from the 'dyers' (bapheis), however, who formed a separate guild (IHierapJ 50 and 195). 
tion of the theatre (two levels of the architrave) to Apollo Archegetes ("the Founder'), to other gods of the homeland, and to the emperors Septimius Severus and Caracalla. ${ }^{59}$ And beyond the Glykon inscription, none of the other four families who included the purple-dyers (or its leadership, 'the board of presidents of the purple-dyers', tō synedriō tēs proedrias tōn porphyrabaphōn) in funerary arrangements expressly indicate any Jewish connections regarding either the family who owned the grave or the guild in question. ${ }^{60}$

When the 'sacred guild of purple-dyers' (hē semontatē ergasia tōn porphyrabaphon) set up its own honorary monuments for civic and imperial officials, once again there is no indication that they were distinctively Jewish in composition. ${ }^{61}$ It is certainly possible, however, that the guild included Jews in its membership when such honorary activities took place (the membership would no doubt change over generations), especially in light of evidence from elsewhere concerning Jews' interactions with imperial-connected individuals who were not Jewish. ${ }^{62}$ So, although we cannot necessarily assume that the purple-dyers were solely gentile, we do know that they were not solely Jewish during the era of the Glykon inscription.

In light of this, there are two main possibilities regarding the composition of these guilds. In either case we have evidence not only for the participation and integration of Jews in civic life but also for Jewish affiliations with, or even memberships in, local occupational associations at Hierapolis. On the one hand, if the guild was composed exclusively of gentiles, as Judeich and Cichorius suggested early on, we have a Jew following burial conventions of non-Jews in Hierapolis (and Asia generally) by including guilds in funerary provisions. ${ }^{63}$ In this case, the reason for Glykon's asking these guilds (instead of a Jewish group, for instance) to perform the grave rituals would presumably relate to the fact that he had contacts with purple-dyers and carpet-weavers in the context of commercial networks, perhaps as a regular customer or benefactor of the groups. ${ }^{64}$

59 Tullia Ritti, Fonti letterarie ed epigrafiche (Hierapolis Scavi e Ricerche 1; Rome: Giorgio Bretschneider Editore, 1985), pp. 108-13.

${ }^{60}$ IHierapJ 133 (designated simply tōn porphyrabaphōn); IHierapJ 227b (referring to tō synedriō tēs proedrias tōn porphyrabaphōn, 'the board of presidency of the purple-dyers'); IHierapPenn 23 (referring to the proedria tōn porphyrabaphōn, 'the presidents of the purple-dyers'). Cf. IHierapJ 156; IHierapPenn 37 (each involving a purple-dealer [porphyropōlēs] with no Jewish connection involved).

61 IHierapJ 42; IHierapJ 41 = IGR IV 822 (probably III CE). The use of 'most sacred' is typical of associations, organisations, and civic bodies when they express their own identities, namely, when they are having the monument inscribed (see note 20; cf. IHierapJ 36, 40). Other inscriptions relating to the purple-dyers at Hierapolis were inscribed under the auspices of the polis or by families in connection with burial, where less praising language is used.

62 See Harland, Associations, pp. 219-28.

${ }^{63}$ Carl Humann, Conrad Cichorius, and Walther Judeich, Altertümer von Hierapolis (Jahrbuch des kaiserlich deutschen archäologischen Instituts, Ergänzungsheft 4; Berlin: Georg Reimer, 1898). pp. 46, 51, 174

64 It is unlikely that Glykon is himself a member in one of the guilds in question since he does not identify his occupation (as one would expect). It was common for wealthier individuals to call on the funerary-related services of a guild to which they did not belong (see the earlier discussion of socio-economic status and note 47). 
What seems even more likely is that, although consisting principally of gentiles, at Glykon's time these two guilds included individual devotees of the Jewish God (Jews, or perhaps gentile sympathisers or judaising Christians), ${ }^{65}$ who happened to be purple-dyers or carpet-weavers. Paul R. Trebilco is among those who mention this third possibility, yet he is hesitant to take a stand on which of the three options seems most or least likely. ${ }^{66}$ Suggesting the presence of devotees of the Jewish God in the guilds would have the advantage of better accounting for Glykon's request that gentile guilds perform the customary grave-ceremony on Jewish holidays, and we know that Jews sometimes did engage in clothing and other related occupations. ${ }^{67}$

If this is indeed the case, then we can begin to imagine processes whereby ordinary gentiles might become gentile sympathisers or god-fearers (such as those at Aphrodisias in the fourth century), since the Glykon family's choice to corporately involve these guilds in celebrating Jewish festivals would involve some gentiles who had little or no previous involvement in Jewish practices per se. Social network connections based on common occupation could become the basis of new adherences, in this case perhaps leading to an increase in the number of gentiles with some level of attachment to the Jewish God or community ${ }^{68}$

If there were Jews (or sympathisers) as members of these guilds at Hierapolis, as I argue, Glykon's reasons for choosing these two guilds (rather than other known guilds) would involve a combination of factors, including his contacts (for commercial and/or benefaction purposes) with both Jews and gentiles and his ethno-cultural affiliations with fellow-Jews (or at least gentile devotees of the Jewish God) in Hierapolis. It is this combination of attachments which makes this third option concerning the mixed composition of the guild most effective in making sense of our evidence. The theory that Jews at Hierapolis maintained affiliations with or memberships in other groups or associations within the city is also consistent with Jewish evidence from other

65 On Christians at Hierapolis, see note 80 below.

66 Trebilco, Jewish Communities, pp. 178-79. Kraabel (Judaism, pp. 134-35) is among the first to mention this option. Tullia Ritti ('Nuovi dati') further explores this possibility and is less hesitant in suggesting that this may be a mixed guild. Miranda ('La comunità giudaica', pp. 14144) discusses evidence of Jewish occupational organisations (in Palestine and Alexandria) at some length, and suggests that the purple-dyers were likely Jewish and that the carpet-weavers may have been mixed. The new edition of Emil Schürer's work (by Vermes, Millar and Goodman) states that 'the members of the guilds must also have been influenced by Judaism' (Emil Schürer, The History of the Jewish People in the Age of Jesus Christ (175 B.C.-A.D. 135), ed. Geza Vermes et al.; Edinburgh: T. \& T. Clark, 1973-87, vol. 3, p. 27). Cf. $A E$ (1994) 510, no. 1660 on the possibility of theosebeis.

67 Cf. CIJ 787, 873, 929, 931; Acts 16:14-15; 18:2-3.

68 Compare the situation in fourth-century Aphrodisias, where several Jews and god-fearers came from occupations related to clothing production or sale (rag-dealer, fuller, boot-maker, linen-worker, and purple-dyer) and where, in at least one case, the occupation of a named Jew (a bronzesmith) matches that of two god-fearers, who are also bronzesmiths (IJO II 14b, lines 25, 46, 53; cf. Reynolds and Tannenbaum, Jews and God-Fearers, pp. 116-23). Tessa Rajak and David Noy have shown that even those who were designated archisynagogoi may have been nonJewish benefactors of Jewish groups, for instance. See Rajak and Noy, 'Archisynagogoi: Office, Title and Social Status in the Greco-Jewish Synagogue', JRS 83 (1993), pp. 75-93; cf. Rajak, Jewish Dialogue, pp. 373-91. 
areas. ${ }^{69}$ In cases where we know the occupation of Jews there is a range of activity comparable to the known guilds, and the fact that occupations are mentioned at all on Jewish monuments suggests that this was an important component in their identities. ${ }^{70}$ So it is not too surprising to find Jews affiliating with their fellow-workers within occupational networks and guilds.

\section{Conclusion: Dynamics of Acculturation and Interaction in the Diaspora}

Throughout this discussion we have encountered members of minority cultural groups, namely Jews at Hierapolis, adopting and adapting to local cultural practices and interacting with their Greek or Roman neighbours. The case of Hierapolis demonstrates well some dynamics of cultural and structural assimilation in the ancient context, and it is worthwhile placing this evidence within a broader social scientific framework here. ${ }^{71}$

J. Milton Yinger's sociological study defines assimilation as 'a process of boundary reduction that can occur when members of two or more societies or of smaller cultural groups meet'. ${ }^{72}$ Yinger and others distinguish between sub-processes of assimilation, the most important here being (1) cultural assimilation, or acculturation, and (2) structural assimilation. ${ }^{73}$ First, acculturation refers to processes which occur when individuals or groups of differing cultural backgrounds come into first-hand contact with one another, with resulting transformations in the cultural patterns of one or both groups. ${ }^{74}$ Acculturation can involve the selection, adoption, and adaptation of a variety of cultural traits including language, dress, religion, funerary practices, and other cultural conventions, beliefs, and values of a particular cultural group. This process is selective and transformative as "the patterns and values of the receiving culture seem to function as selective screens in a manner that results

69 See Harland, Associations, pp. 200-10. For Jews in age-based, gymnastic organisations, for instance, see Louis Robert, 'Un corpus des inscriptions juives', Hellenica 1 (1946), pp. 100-101 (ephebes at Iasos; II-III CE); Louis Robert, 'Épitaphes d'Eumeneia de Phrygie', Hellenica 11-12 (1960), pp. 436-39 (elders at Eumeneia; II-III CE); Gert Lüderitz, Corpus jüdischer Zeugnisse aus der Cyrenaika (Beihefte zum Tübinger Atlas des Vorderen Orients; Wiesbaden: Dr. Ludwig Reichert Verlag, 1983), pp. 11-21, nos. 6-7 (ephebes at Cyrene; late I BCE-early I CE).

${ }^{70}$ See van der Horst, Ancient Jewish Epitaphs, pp. 99-101; Shaye J. D. Cohen, “"Those Who Say They Are Jews and Are Not": How Do You Know a Jew in Antiquity When You See One?', in Diasporas in Antiquity (ed. Shaye J. D. Cohen and Ernest S. Frerichs; BJS 288; Atlanta: Scholars Press, 1993), p. 10; Reynolds and Tannenbaum, Jews and God-Fearers, pp. 116-23.

71 For others who have drawn on such social scientific insights in studying religious and immigrant groups in the ancient context see David L. Balch, 'Hellenization/acculturation in 1 Peter', in Perspectives on First Peter (NABPR Special Studies Series 9; Macon: Mercer University Press, 1986), pp. 79-101; Barclay, Jews; David Noy, Foreigners at Rome: Citizens and Strangers (London: Gerald Duckworth, 2000).

72 J. Milton Yinger, 'Toward a Theory of Assimilation and Dissimilation', Ethnic and Racial Studies 4 (1981), p. 249.

73 Cf. Yinger, 'Toward a Theory'; Martin N. Marger, Race and Ethnic Relations: American and Global Perspectives (2nd ed.; Belmont, CA: Wadsworth Publishing Company, 1991), pp. 116-29.

74 Cf. Robert Redfield, Ralph Linton, and Melville J. Herskovits, 'Memorandum for the Study of Acculturation', American Anthropologist 38 (1936), p. 149. 
in the enthusiastic acceptance of some elements, the firm rejection of other elements'; furthermore, 'the elements which are transmitted undergo transformations' in the process. ${ }^{75}$

It is important to emphasise that in this theoretical framework acculturation can progress significantly without the disintegration of a group's boundaries in relation to a larger cultural entity. Cultural adaptation can be a twofold process entailing the 'maintenance of cultural integrity as well as the movement to become an integral part of a larger societal framework', as John W. Berry points out. ${ }^{76}$

The second main sub-process of assimilation, structural assimilation, entails both informal and formal levels. At the informal level, individual members of a given ethnic or cultural group can interact with persons from other cultural groups through personal, social network connections, including memberships in neighborhoods, clubs, and associations. ${ }^{77}$ The formal level of structural assimilation involves members of a particular minority cultural group participating in political, legal, social, or economic institutions of society.

These concepts about processes of assimilation provide a framework in which to to make better sense of the ancient evidence - albeit fragmentaryfor Jewish or other immigrant groups within the cities of the Roman empire. Moreover, both the form and content of the Jewish epitaphs at Hierapolis illustrate both cultural and structural assimilation. First of all, we have seen that the form of Jewish grave-inscriptions indicates acculturation to patterns of other non-Jewish graves from the same locale. ${ }^{78}$ Moving beyond the form of epitaphs to the content and its implications, we should notice important, though subtle, evidence of formal structural assimilation in relation to important institutions of the polis. The inclusion of formal institutions, usually the civic ('most sacred') treasury, as recipients of fines in many (nine) Jewish inscriptions at Hierapolis (and on Jewish epitaphs elsewhere) implied some level of civic responsibility for preservation or maintenance of the family tomb. ${ }^{79}$ Violators would have to answer not only to the descendants of the family, if any, but also to the city of Hierapolis itself, so to speak. Including local associations, alongside civic institutions or alone, was thought to further bolster this insurance that the family grave would remain intact and undisturbed.

There are other signs of formal structural assimilation among Jews here. Like their non-Jewish counterparts, nearly half (ten) of the Jewish epitaphs

75 H. W. Barnett et al, 'Acculturation: An Exploratory Formulation', American Anthropology 56 (1954), pp. 973-1002.

76 John W. Berry, 'Acculturation as Varieties of Adaptation', in Acculturation: Theory, Models and Some New Findings (ed. Amado M. Padilla; AAAS Selected Symposium 39; Boulder, Colorado: Westview Press, 1980), p. 13.

77 Cf. Yinger, 'Toward a Theory', p. 254; Marger, Race and Ethnic Relations, p. 118.

78 Among these standard inscriptional patterns (including the common vocabulary used) are: (1) identification of the owner(s) of the tomb and surrounding area; (2) stipulations that no one else, beyond those designated, is to be buried on the site; (3) preventative measures of setting fines should the instructions be violated; (4) arrangements for payment of such fines to civic institutions (treasury or elders' organisation) and/or local associations (e.g. Jewish synagogues, guilds); and, (5) deposit of a copy of the inscription in the civic archives.

79 Cf. IJO II 172 (Akmoneia), 216 (Termessos), 233, 238 (Korykos). 
from Hierapolis (the Glykon grave included) also clearly mention that a copy of the epitaph was placed in the archives. This, too, has a structural significance beyond its seemingly incidental mention. For placing a copy in the civic archives further ensured that, if anyone should fail to obey the will of the deceased or actually modify (or remove) the original inscription from the tomb, legal action could follow. This expectation of justice from relevant civic institutions is a significant indication of structural integration in local society.

It is within this context of interaction and acculturation that we can better understand the Glykon family grave itself. If, on the one hand, Glykon and his family were gentile sympathisers (or judaising Christians, for instance) ${ }^{80}$ who had adopted important Jewish practices, which is possible though difficult to establish, then this provides an interesting case of gentile acculturation to the ways of local Jews while also continuing in burial customs characteristic of Hierapolis and Asia Minor. Furthermore, the involvement of a guild which did include gentiles in its number (the purple-dyers) is suggestive of at least some level of acculturation to Jewish practices on the part of these gentile guild-members at Hierapolis; yet here it is the family, not the gentiles in the guilds, who have chosen to have the guilds participate on Jewish holy days and on a Roman festival. Unlike the case of the god-fearers at Aphrodisias, we have no clear indication that the gentile guild-members were members in the synagogue or in an association devoted solely to the Jewish God.

If, on the other hand, Glykon and his family were Jews, this inscription provides further evidence of both cultural and structural assimilation among Jewish families at Hierapolis. We have found that the fabric of this family's identity consisted of intertwined Jewish, Roman, and Hierapolitan strands. Most prominently in setting this family apart as Jewish is the concern to have the grave visited on the festivals of Passover and Pentecost. While many Jewish families did assert their identity (in relation to non-Jews) by using the designation Ioudaios, the Glykon inscription stands out among the epitaphs of Hierapolis, and even Asia Minor or the empire, in its special concern to carry on Jewish observances even after death, thereby continuing to express this aspect of identity within Hierapolis indefinitely.

At the same time, Glykon felt himself to be Roman, both in proudly indicating his status as Roman citizen and by choosing to include the Roman New Year festival as a time when the family would be remembered by a guild in Hierapolis. In fact, the rarity of epigraphic evidence concerning the celebration of this Roman festival in the provinces draws further attention to its significance here as a sign of Romanisation among Jews.

Alongside these Jewish and Roman facets of identity, the family clearly

80 Literary evidence shows that followers of Jesus lived at Hierapolis already in the first century (Colossians 4:13). The prophetic daughters of Philip, bishop Papias, and bishop Apolinarius are also associated with Hierapolis in the second century (cf. Eusebius, $H E$ 3.31.3, 3.36.1-2, 4.26.1). The earliest openly Christian inscriptions from Hierapolis date to Byzantine times, when the martyrium associated with Philip was established (cf. IHierapJ 22, 24; fifth century or later). Attempts by those such as Ramsay to identify other inscriptions as Christian based only on the inscription's use of 'unusual' language are problematic at best (e.g. IHierapJ 227 with notes by Judeich refuting Ramsay's suggestion of Christianity here; see Ramsay, Cities and Bishoprics of Phrygia, pp. 118-19, no. 28). 
experienced a sense of belonging within the community of Hierapolis specifically in many respects. At the formal structural level, this family, like other Jews, deposited a copy of the inscription in the civic archives, indicating an expectation of some level of justice from local legal procedures and institutions. Furthermore, these Jews were acculturated to Hierapolitan practice in leaving 'grave-crowning funds' and followed regional custom in entrusting their final bequest to occupational associations. Not only that, but the family also chose one of the most popular and, it seems, widely trusted local guilds to fulfill this duty.

Both Glykon and the devotees of the Jewish God who belonged to the guilds of purple-dyers and carpet-weavers illustrate the potential for multiple affiliations with sub-groups of local society. This is an important factor in the process of informal structural assimilation. Moreover, information concerning the Glykon family, as well as other Jews at Hierapolis, points toward significant levels of integration on the part of these Jews within the society of Greco-Roman Hierapolis alongside a continued sense of being Jewish.

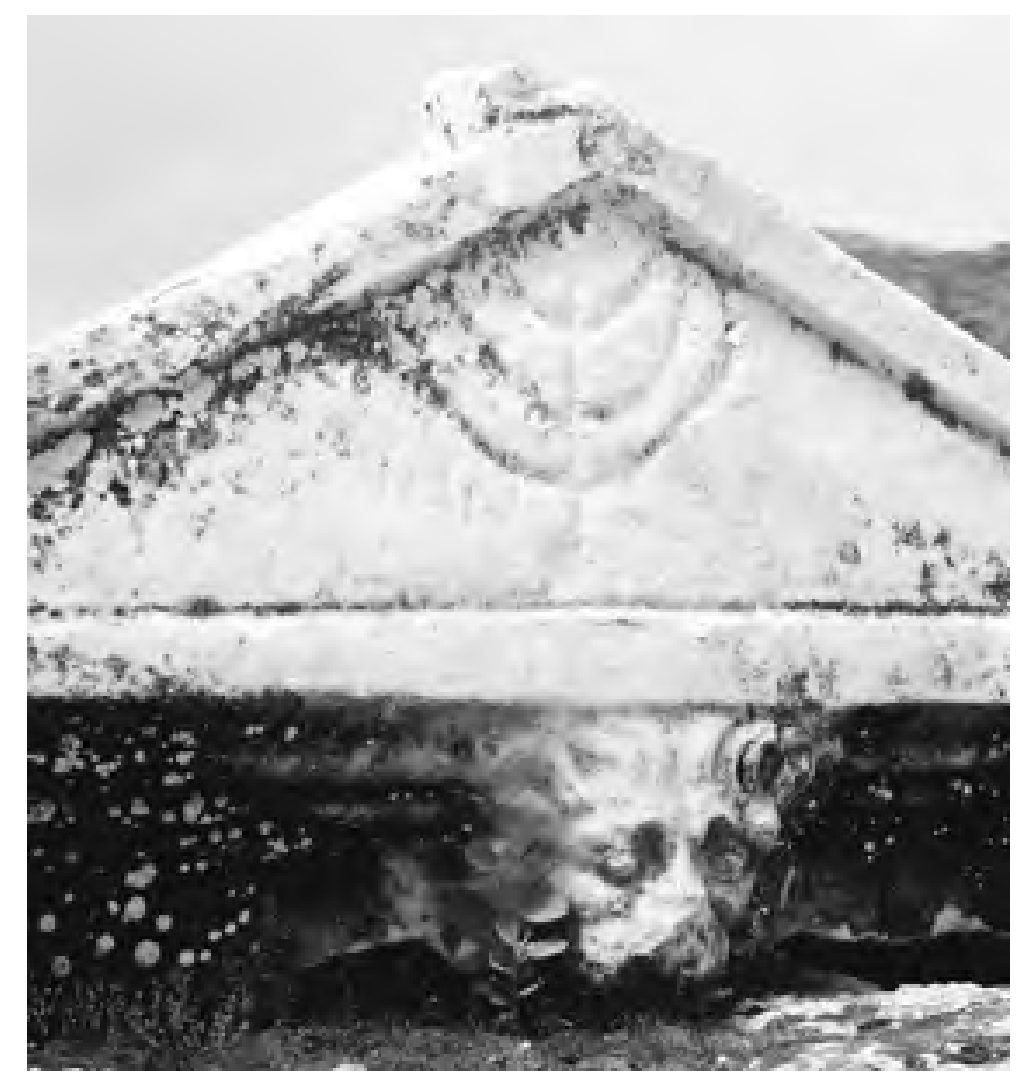

Figure 1. Grave 'of the Judeans' depicting a menorah and lion (IHierap Mir 6). Photo by author. 


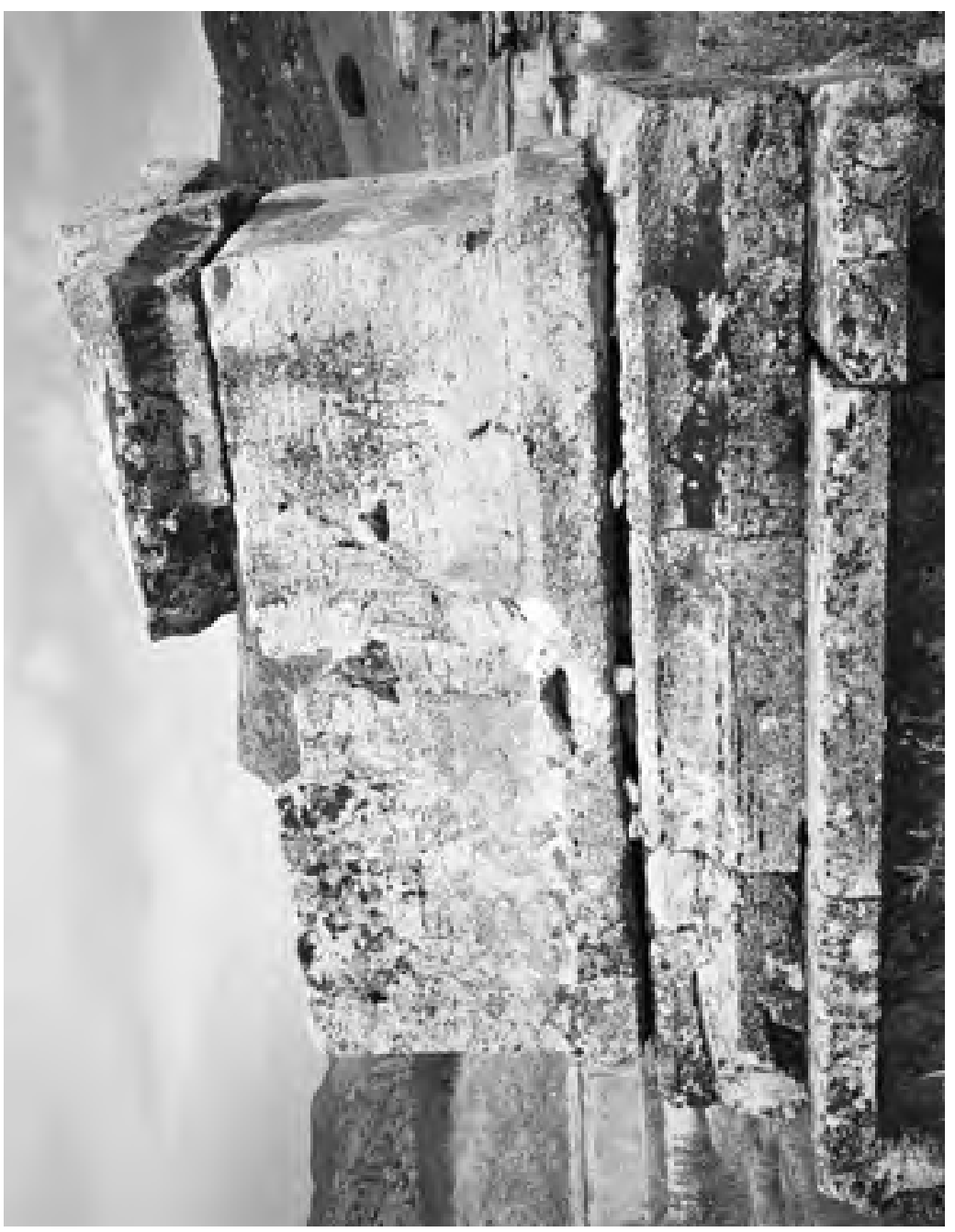

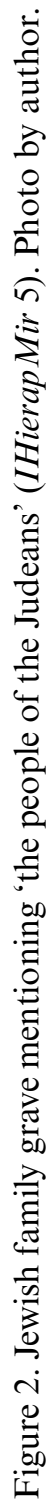




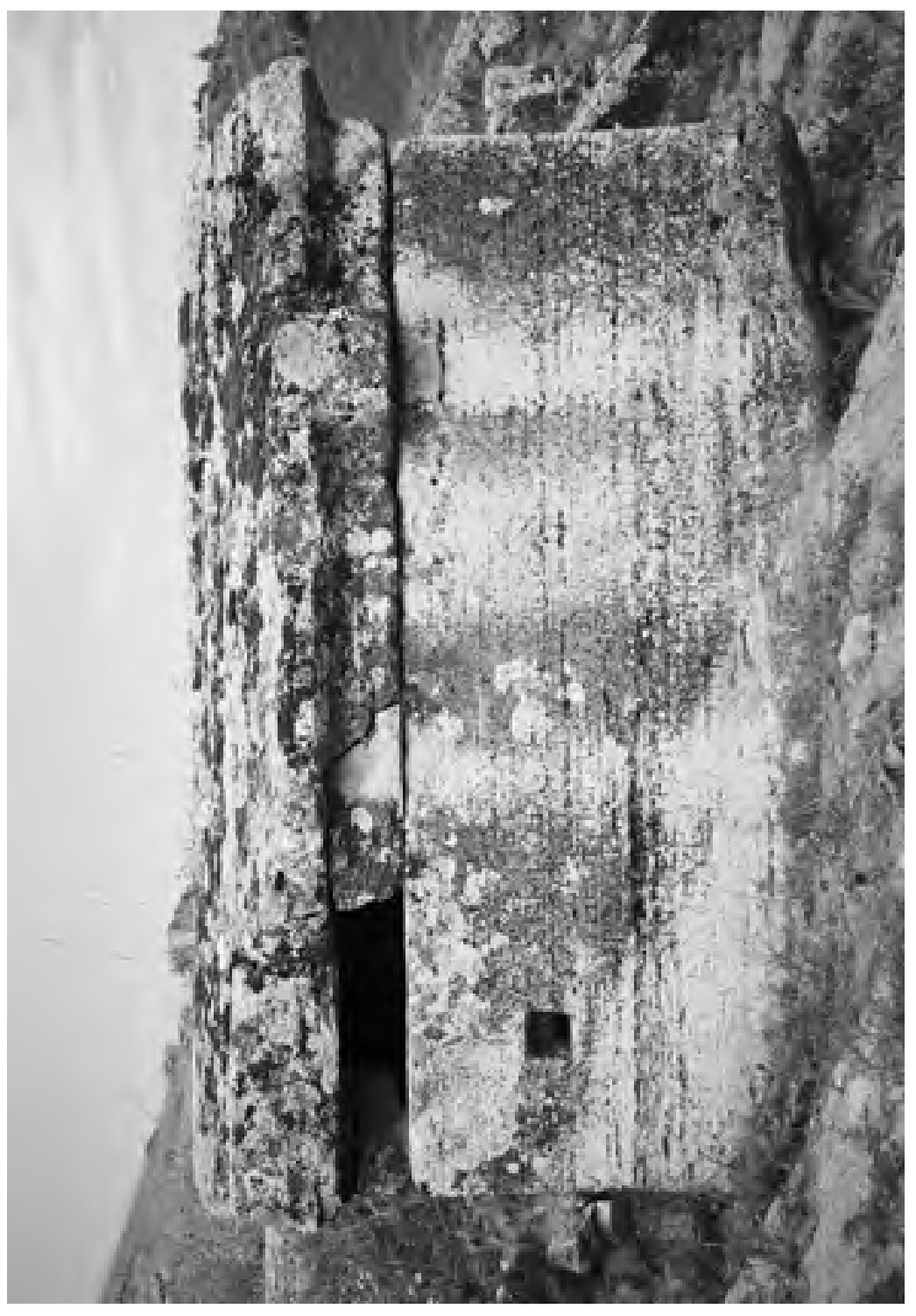

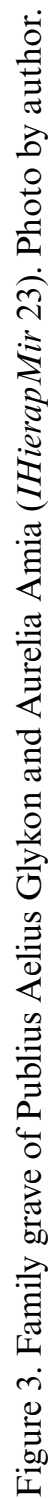

